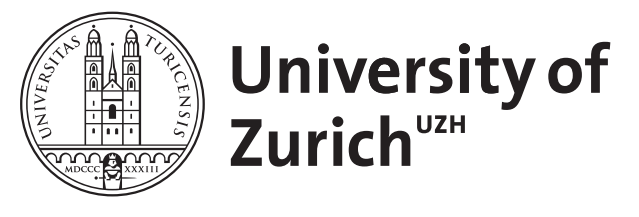

\title{
International regulatory reform and financial taxes
}

Alexander, Kern

\begin{abstract}
This article examines the effectiveness and feasibility of some of the main proposals for financial taxes by analysing their economic rationale and impact and some related international trade law issues regarding their implementation. The advantages and disadvantages are considered in terms of their effect on risk mitigation, market liquidity and the provision of sustainable revenue. The article suggests that financial transaction taxes, especially those applied to currency transactions and exchange-traded and over-the-counter derivatives, could serve regulatory objectives while raising adequate revenue to assist governments in paying for the social costs of financial crises and providing global public goods.
\end{abstract}

DOI: https://doi.org/10.1093/jiel/jgq036

Posted at the Zurich Open Repository and Archive, University of Zurich ZORA URL: https://doi.org/10.5167/uzh-47003

Journal Article

Originally published at:

Alexander, Kern (2010). International regulatory reform and financial taxes. Journal of international economic law : JIEL, 13(3):893-910.

DOI: https://doi.org/10.1093/jiel/jgq036 


\title{
INTERNATIONAL REGULATORY REFORM AND FINANCIALTAXES
}

\author{
Kern Alexander*
}

\begin{abstract}
This article examines the effectiveness and feasibility of some of the main proposals for financial taxes by analysing their economic rationale and impact and some related international trade law issues regarding their implementation. The advantages and disadvantages are considered in terms of their effect on risk mitigation, market liquidity and the provision of sustainable revenue. The article suggests that financial transaction taxes, especially those applied to currency transactions and exchange-traded and over-the-counter derivatives, could serve regulatory objectives while raising adequate revenue to assist governments in paying for the social costs of financial crises and providing global public goods.
\end{abstract}

\section{INTRODUCTION}

The costs of the financial crisis of 2007-09 are rising exponentially and will impose huge economic and social costs on both developed and developing countries for generations to come. The crisis has also made it extremely difficult for developed countries to honour their pledges made at the Gleneagles G7 Summit in 2005 to increase their financial support for global public goods such as the United Nations (UN) Millennium Development Goals (MDGs). Governments will thus be obliged to generate additional revenue, and to shape taxation accordingly. This article examines the effectiveness and feasibility of several financial taxes, including a bank balance sheet tax, a currency transaction tax (CTT) and a broader financial transaction tax (FTT). ${ }^{1}$ The article argues that financial taxes are becoming part of the international regulatory landscape and will eventually become an integral component of prudential regulatory regimes. The article also suggests that financial taxes can serve as innovative sources of finance to pay for

\footnotetext{
* Professor of Banking, Commercial and Financial Market Law, Law Faculty, University of Zürich; Senior Research Fellow, Centre for Financial Analysis and Policy, The Judge Business School, University of Cambridge. E-mail: k.alexander@jbs.cam.ac.uk

${ }^{1}$ A financial transaction tax is a generic term covering a number of possible taxes that could apply to certain securities investments, derivative contracts or other financial products including commodities.
} 
the social costs of financial crises while also providing for global public goods. $^{2}$

Financial policymakers are debating whether and how to use financial taxes to enhance the regulation of financial markets. ${ }^{3}$ Financial taxes can have three main objectives: (i) to limit excessive risk-taking, (ii) to provide an insurance or resolution fund for systemically important institutions and (iii) to help pay for global public goods. It should be emphasized that these three objectives are separable, both in their economic rationale and in practice. The first objective, limiting excessive risk-taking, is derived from the desire to price risk efficiently. In this case, how the funds are used subsequently is not of primary concern. Second, the proposition that such funds might be used to build an insurance fund is an entirely separate argument related not to mitigating the riskiness of financial transactions but to pricing accurately the implicit insurance provided to institutions deemed too big or too inter-connected to fail. The provision of assistance to those most affected by ill-chosen risk-taking is a third component of an efficient pricing strategy. Hence the objective of efficient pricing may be pursued by adopting all three goals at once, or by pursuing them separately.

\section{BANK BALANCE SHEET TAXES}

\section{A. Domestic efforts}

Sweden adopted a so-called 'stability fee' in 2009 that was a direct levy on Swedish banks and credit institutions to provide a fund to pay for the resolution of failed Swedish banks. ${ }^{4}$ Banks will be required to pay the levy on an annual basis at a rate of $0.018 \%$ of each institution's liabilities, excluding equity capital and certain subordinated debt, based on audited balance sheets. ${ }^{5}$ Banks are not expected to make their first payments into the fund until 2010 after the balance sheets are audited and the government has injected an initial 15 billion kronor into the fund. Beginning in 2011, the bank levy will increase to $0.036 \%$ of liabilities with the government planning to introduce a weighted charge as well. Banks with riskier assets would pay a higher percentage. Such a tax on bank liabilities may result, however, in banks being double-charged on their liabilities if they have retail or wholesale

${ }^{2}$ Global public goods can be defined as goods or services that are not provided by the market because of market failure and which governments can therefore justify providing on efficiency grounds in order to enhance economic and social outcomes. See generally Anthony B. Atkinson, 'Innovative Sources to Meet a Global Challenge', in A.B. Atkinson (ed), New Sources of Development Finance (Oxford: Oxford University Press, 2005) 1-3.

${ }^{3}$ See International Monetary Fund, 'A Fair and Substantial Contribution by the Financial Sector', Final Report for the G-20, IMF Final Report, http://www.imf.org/external/np/g20/ pdf/062710b.pdf (visited 25 July 2010).

${ }^{4}$ See Anders Borg, 'Letter to G20 Finance Ministers' (Ministry of Finance, Sweden, 2010, on file with the author).

5 Ibid. 
deposits which often require reserve requirements at the central bank. The Swedish levies are allocated to a stability fund managed by the Swedish National Debt Office. The government plans to continue levying the fee over a period of 15 years until the revenue generated reaches $2.5 \%$ of Swedish gross domestic product (GDP). ${ }^{6}$

The Swedish stability fee serves as a model for other countries. The Obama administration proposed a similar fee in March 2010 that it called a 'financial crisis responsibility fee', to be imposed at a rate of $0.15 \%$ on the largest US banks in order to repay US taxpayers for the costs of the US bank bailout programme. Congress rejected the Obama bank tax in the DoddFrank Act by requiring regulators to impose several different assessments on the largest US banks and non-bank financial institutions to cover the costs of the government's expanded supervisory and resolution responsibilities. $^{7}$ Unlike other countries, which are adopting bank taxes designed to curb future risk-taking, the US assessments are retrospective in effect because they are designed mainly to reimburse taxpayers for the direct costs of the government's bank bailouts and to establish a fund to support the future resolution of financial institutions.

Germany, France and the UK have announced that they too will adopt a levy or stability tax on bank balance sheets. ${ }^{8}$ The UK government proposed in its 2010 budget a graduated tax on bank liabilities and equity where the banking group's aggregated liabilities exceed $£ 20$ million. The tax would be based on all liabilities and equity excluding tier-1 capital, insured retail deposits, repurchase agreements on sovereign debt and retail insurance reserves. ${ }^{9}$ It would be imposed at a rate of $0.04 \%$ in 2011 increasing to $0.07 \%$ in 2012 with a reduced rate for longer maturity funding (i.e. greater than 1 year) at $0.02 \%$ in 2011 rising to $0.035 \%$ in $2012 .{ }^{10}$ Significantly, unlike the Swedish and US bank taxes, the German, French and UK taxes are not considered to be insurance against bank failure and liability to pay the tax does not indicate that the bank is too big to fail. The revenues generated from the levy are not intended to pay for future bank bailouts

\footnotetext{
${ }^{6}$ The Swedish government estimates $2.5 \%$ of GDP to be the cost to the Swedish economy of a full-scale banking crisis. Ibid.

${ }^{7}$ The Wall Street Reform and Consumer Protection Act of 2010 (Dodd-Frank Act), Pub. L. 111-203 (21 July 2010).

${ }^{8}$ HM Treasury, 'Bank Levy', Press Release and Joint Statement of the UK, French and German Governments, 4 June 2010 (announcing that the UK government would impose a bank levy from 1 January 2011 and that the UK, French and German governments would impose similar bank balance sheet levies). The UK levy would be based on the 'consolidated balance sheet' of banking groups and the 'aggregated subsidiary and branch balance sheets of foreign banks and banking groups operating' in the UK where these institutions have 'relevant aggregated liabilities' of $£ 20$ million or more. See HM Treasury, Financial Times, 8 June 2010, 12 .

${ }^{9}$ Ibid.

${ }^{10}$ Ibid.
} 
or indirect interventions. Instead, they are meant to be charges on the broader economic and systemic risks posed by the banking sector. The different design and objectives of these national bank taxes may affect bank risk-taking differently across jurisdictions, which suggests that more cross-border coordination is needed among national authorities to ensure that these taxes achieve their objectives and are not circumvented through arbitrage.

\section{B. International initiatives}

The Group of 20 (G-20) Heads of State requested the International Monetary Fund (IMF) to examine the desirability and feasibility of various types of financial taxes and to report its conclusions to the G-20. ${ }^{11}$ The IMF issued its report in June 2010 recommending that countries consider adopting two taxes: a 'Financial Stability Contribution' (FSC) and a 'Financial Activities Tax' (FAT). ${ }^{12}$ The FSC is a balance sheet tax that would be based on the bank's total liabilities minus equity, insured deposits and insurance policyholder reserves, with most of the proceeds going to a bank-resolution fund. In contrast, the FAT would be levied on the profits and remuneration of financial institutions and the proceeds would go to the general revenue fund. ${ }^{13}$ The FSC is primarily designed as an insurance fund to pay retrospectively for the resolution or bailout of a large systemically important or too-interconnected-to-fail bank or financial institution. In contrast, the FAT would primarily be applied prospectively to deter excessive risk-taking.

The IMF's recommended financial stability contribution is similar to the financial stability tax discussed above that Sweden adopted in 2009 and which was based on bank liabilities and equity. The G-20 and the Financial Stability Board are considering proposals that would recommend that countries adopt a balance sheet tax and levy similar to the IMF's proposals. These taxes, however, have met with resistance from some developed countries and many developing countries because they might impose disproportionate costs on countries whose economies rely more on bank finance. ${ }^{14}$ Moreover, some G-20 countries which had regulated their banks more strictly before the crisis and hence did not provide direct bailouts to their banks

${ }^{11}$ The G-20 Pittsburgh Communiqué stated that the IMF should 'prepare a report for our next meeting [June 2010] with regard to the range of options countries have adopted or are considering as to how the financial sector could make a fair and substantial contribution toward paying for any burden associated with government interventions to repair the banking system.' See G-20, 'Leaders' Statement: The Pittsburgh Summit', 24-25 September 2009, para 16. See also IMF Final Report, above n 3, at 1.

${ }^{12}$ See IMF Final Report, above n 3.

${ }^{13}$ Ibid, at 2-3.

${ }^{14}$ Developing countries usually have under-developed capital markets and rely mainly on a bank-led finance system. See Gerald M. Meier and James E. Rauch, Leading Issues in Economic Development, 7th ed. (New York: Oxford University Press, 2000) 138-46. 
(i.e. Canada, China, India and Japan) have opposed a balance sheet tax and have led opposition to the adoption of such a tax on an international basis. Indeed, these countries influenced the text of the G-20 Toronto Summit Communique to state that each country would be free to adopt whatever tax measures it deemed appropriate for the needs of its economy and financial system. Another criticism of the bank balance sheet tax is that it will fail to deter banks from engaging in excessive risk-taking and will not generate adequate revenue to pay for a resolution fund because most banks will avoid the tax by shifting risky assets and liabilities off balance sheet to affiliates and related entities located outside the taxing jurisdiction. These weaknesses of the proposed bank balance sheet tax suggest that policy-makers should consider the merits of a FTT that would be applied by national governments and collected by banks and dealers with the support of transnational clearing and settlement houses.

\section{FTTS}

The recent crisis has raised questions about the possibility of a Tobin or transactions tax to restrain the explosive growth of financial transactions in recent years. In considering such a tax, it should be borne in mind that most countries do not impose a sale or value-added tax on financial services transactions. ${ }^{15}$ The idea behind a FTT has been attributed to Nobel Laureate James Tobin who proposed a CTT in the 1970s primarily to limit the destabilizing influence of the growing volume of very short-term foreign exchange transactions and to enhance control over the financial aspects of macro-economic policy. ${ }^{16}$ Since Tobin's original proposal, the idea of a FTT has been developed by economists and civil society groups as a possible source of revenue to finance global development objectives. ${ }^{17}$ Recently, the global financial crisis has brought the issue back on the agenda with the G-20's efforts to rebuild the financial architecture. Unlike the pre-crisis literature, proposals for a FTT have gained considerable traction, both as a

15 The European Commission is examining an EU financial transaction tax, while the European Parliament has generally endorsed the broad outlines of a tax and the need for EU institutions to develop a unified position on the issue. Commission of the European Communities, 'Innovative Financing at a Global Level', Commission Staff Working Document, SEC (2010) 409, 1 April 2010 and European Parliament, 'Motion for a Resolution to Wind-Up the Debate by the Commission Pursuant to Rule 110 (2) of the Rules of Procedure on Financial Transaction Taxes - Making Them Work', B7 0000/2009, 8 January 2010.

${ }^{16}$ See James Tobin, 'A Proposal for International Monetary Reform', 4 Eastern Economic Journal 153 (1978), at 154. See also James Tobin, The New Economics One Decade Older, The Eliot Faneway Lectures on Historical Economics in Honour of Foseph Schumpeter (Princeton: Princeton University Press, 1974).

17 Mahbub ul Haq, Inge Kaul, Isabelle Grunberg (eds), The Tobin Tax: Coping with Financial Volatility (New York: Oxford University Press, 1996). 
financial stability instrument and as a way to pay for global public goods, such as the UN MDGs and climate-change policies.

This section suggests that the effectiveness and feasibility of a FTT will depend on how well it satisfies the following criteria: (i) achieves a balance of economic benefits in terms of risk mitigation that does not significantly distort the market nor undermine liquidity; (ii) generates adequate revenue to pay for public goods; (iii) is collected and monitored through clearing and settlement infrastructure subject to central bank oversight; and (iv) complies with applicable international law.

\section{A. The economic rationale}

In considering the merits of a FTT, one should bear in mind that the object of economic activity is to produce goods and services. Financial transactions are the means by which the production of goods and services is funded. In the $1960 \mathrm{~s}$, international trade grew by $8.2 \%$ a year, which, together with long-term investment flows, was financed by foreign exchange transactions that were roughly double the value of the trade deals themselves. ${ }^{18}$ In recent years, however, the volume and value of transactions have grown much more rapidly than the underlying production and trade. Between 2000 and 2007, while growth in international trade slowed to just $5.8 \%$ per year, the value of foreign exchange transactions rose to more than 80 times the value of the underlying trade and long-term investment. ${ }^{19}$

Similarly, the growth of derivatives markets and in particular of credit default swaps (CDSs) has grown dramatically with the total notional value of such contracts rising from just over $\$ 1$ trillion in 1986 to around $\$ 516$ trillion in $2007 .{ }^{20}$ The CDS market was at the centre of the financial distress in September 2008 when Lehman Brothers collapsed. The collapse of Lehman Brothers and its aftermath demonstrates that the risk to the economy as a whole was not just a function of complexity and the interconnectedness of transactions, but also of the sheer size of the transactions themselves, relative to the underlying trade or loans on which they were written. For example, Lehman's over-the-counter (OTC) CDS book had a notional value of $\$ 72$ billion, yet Lehman's net exposure to OTC credit default contracts is estimated to have been only about $\$ 5.2$ billion. $^{21}$

${ }^{18}$ See Kern Alexander, John Eatwell, Avinash Persaud and Robert Reoch, 'Crisis Management, Burden Sharing, and Solidarity Mechanisms in the EU' IP/A/ECON/FWC/2010, Report to the European Parliament, 2010, at 31-33.

${ }^{19}$ Ibid.

${ }^{20}$ Bank for International Settlements, 'Semiannual OTC Derivatives Statistics at end-June 2008', http://www.bis.org/statistics/derstats.htm (visited 25 July 2010).

${ }^{21}$ The Bank for International Settlements Estimated in June 2008 that the value of CDSs outstanding in major financial markets was $\$ 57.3$ trillion. Ibid. In late 2008 , the US Depository Trust and Clearing Corporation revealed that the value of CDS transactions was ten times greater than the value of the underlying risk being insured. See Depository 
The ever-growing amount of financial transactions that are based upon a relatively small amount of underlying assets has led some to suggest that policy-makers should give serious consideration to a FTT. ${ }^{22}$ The focus on transaction taxes reflects that the proliferation of financial transactions themselves has become a concern of regulators and that a significant portion of transactions has been characterized as 'socially useless'. ${ }^{23}$ The excessive growth of financial transactions imposes a risk on society as a whole. Those who impose that risk should pay for it. If they do not, then risk is mis-priced. This raises an important question: if financial transactions have grown too large and pose serious risks to financial stability, can a FTT reduce the value and volume of transactions to a more efficient level without undermining liquidity and financial development?

Academic opinion is strongly divided over what utility FTTs have in curbing excessive risk-taking and generating sustainable sources of revenue. Proponents of FTTs view financial markets as characterized by excessive trading activity and short-term speculation, and consider that such speculation generates volatility not only in short-term asset prices, but also in long-term asset prices marked by persistent and dramatic departures from equilibrium. ${ }^{24}$ Keynes observed that this could lead to the 'predominance of speculation over enterprise' with the result that 'enterprise becomes the bubble on a whirlpool of speculation'. ${ }^{25}$ Accordingly, a tax on transactions in securities and other financial instruments would increase the cost of speculative trading, especially for trades with shorter durations, and this would have a stabilizing effect on asset prices. Moreover, the tax would generate revenue needed to assist governments with fiscal consolidation, especially during times of crisis.

Trust and Clearing Corporation, 'Trade Information Warehouse Data', http://dtcc.com/products/derivserv/data_table_i.php (visited 25 July 2010).

${ }^{22}$ Adair Turner, 'What Do Banks Do, What Should They Do and What Public Policies are Needed to Ensure Best Results', March 2010, http://www.fsa.gov.uk/pubs/speeches/at_ 17mar10.pdf (visited 25 July 2010).

${ }^{23}$ Ibid, at 1 .

${ }^{24}$ Lawrence H. Summers and Victoria P. Summers, 'When Financial Markets Work Too Well: A Cautious Case for a Securities Transaction Tax', 3 Journal of Financial Services Research 261 (1989); Joseph E. Stiglitz, 'Using Tax Policy to Curb Short-Term Trading', 3 Journal of Financial Services Research 101 (1989); J. Bradford de Long, Andrei Sheleifer, Lawrence H. Summers, and Robert J. Waldmann, 'Positive Feedback Investment Strategies and Destabilizing Rational Speculation', 45(2) The Journal of Finance 379 (1990); and Stephan Schulmeister, 'A General Financial Transaction Tax: A Short Cut of the Pros, Cons and a Proposal', http://www.makefinancework.org/IMG/pdf/schulmeister_eng.pdf (visited 25 July 2010).

${ }^{25}$ J.M. Keynes, The General Theory of Employment, Interest and Money (London: Macmillan, 1936) 158-59. Keynes also observed that to limit excessive speculation on the stock exchange 'a substantial Government transfer tax on all transactions might prove the most serviceable reform available'. Ibid, at 160 . 
Opponents of transaction taxes generally believe that a high number of transactions-both short- and long-term-are necessary for the price discovery process to work and for the efficient distribution of risk. More transactions lead to a smoothing in asset-price movements towards equilibrium, ${ }^{26}$ and short-term trading is necessary to allow effective hedging and should not, therefore, be limited. Any increase in transaction costs (i.e. a tax) would limit parties' ability to hedge risk, thus reducing liquidity and increasing short-term volatility of asset prices. An alternative, and fundamentally contradictory point, is that globalized and liberalized financial markets make it very difficult to implement a FTT and will result in evasion and circumvention of the FTT, thereby substantially reducing its effectiveness and its revenue-raising capacity.

\section{B. Global public goods}

The crisis has also made it extremely difficult for developed countries to honour their pledges taken at the Gleneagles G7 Summit in 2005 to increase their financial support for global public goods and in particular to achieve the UN MDGs. ${ }^{27}$ At the Gleneagles Summit, the G7 Heads of State promised increased financial support for poverty reduction in the world's poorest countries and to raise Official Development Assistance to $0.7 \%$ of gross national product. These financial commitments, however, have not been met. The World Bank has estimated that since 2005 the resource gap between the financial commitments made by developed countries and their actual expenditures and support levels for global public goods grew substantially and would reach an estimated range of between US\$324 and 336 billion per year sometime between 2012 and $2017 .{ }^{28}$ Even if the global economy improves, the resource gap for developed countries will remain substantial, thus making it difficult for developed countries to fulfil their financial commitments to achieve the MDGs. Consequently, developed countries are considering alternative and innovative sources of finance to pay for their MDG commitments and other global public goods.

${ }^{26}$ Karl F. Habermeier, Andrei A. Kirilenko, 'Securities Transaction Taxes and Financial Markets', 50 IMF Staff Papers 165 (special issue), 2003. See also John Grahl and Photis Lysandrou, 'Sand in the Wheels or Spanner in the Works? The Tobin Tax and Global Finance', 27(4) Cambridge Journal of Economics 597 (2003).

${ }^{27}$ UN General Assembly Resolution, 'United Nations Millennium Declaration', A/Res/55/2, 18 September 2000. The MDGs consist of eight specific goals: (i) eradicating extreme poverty; (ii) achieving universal primary education; (iii) promoting gender equality and empowering women; (iv) reducing child mortality; (v) improving maternal health; (vi) combating HIV/ AIDS, malaria and other diseases; (vii) ensuring environmental sustainability; and (viii) developing a global partnership for development.

${ }^{28}$ Organisation for Economic Co-operation and Development, 'Economic Outlook No 86', http://www.oecd.org/document/18/0,3343,en_2649_34109_20347538_1_1_1_37443,00.html (visited 25 July 2010). 


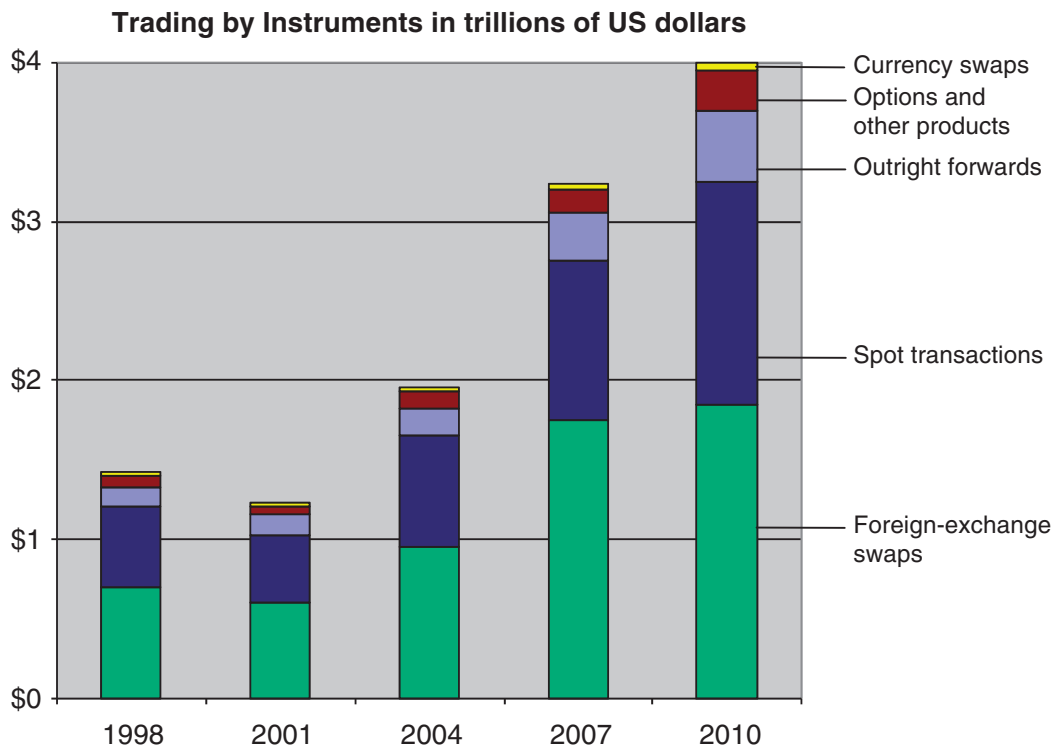

Figure 1. Global foreign exchange market. Source: BIS.

IV. CTT

The foreign exchange market (FX market) is crucial for the functioning of the global financial system because it is the largest and most liquid of the asset class markets. In the post-crisis environment, it has taken on an even greater significance because of the recognized importance of liquidity to the successful operation of the global financial system. Despite the recent economic downturn and associated financial distress in most countries, the average daily turnover in the global foreign exchange market has increased dramatically from just over US $\$ 3$ trillion a day in 2007 to US $\$ 4$ trillion a day in 2010 (Fig. 1). ${ }^{29}$ The vast majority of the market (about 90\%) consists of spot transactions, outright forwards and forex swaps, while non-traditional foreign exchange derivatives and other products (i.e. currency swaps and options) comprise about $10 \%$ of the market (Fig. 1). Most of these trades can be settled within 7 days, which suggests that they are predominantly speculative and have little connection to underlying trade. Although foreign exchange markets generally operated efficiently in the

${ }^{29}$ Bank for International Settlements, 'Triennial Central Bank Survey for Foreign Exchange and Derivatives Market Activity in April 2010 - Preliminary Global Results, September 2010, at 3. Although trading volumes dropped in 2008-09 in the aftermath of the Lehman Brothers' collapse, daily volumes are now expected to grow further because of increased investment in emerging economies and commodity-producing countries and advances in computer trading systems. 
recent crisis, there were considerable disruptions to the foreign exchange swap market before and after the Lehman Brothers' collapse. ${ }^{30}$ Traditionally, most of these transactions were carried out by interbank dealers-the largest investment banks and their dealers-but in 2010 the proportion of transactions carried out by interbank dealers dropped to $39 \%$ while the proportion of transactions carried out by 'other financial institutions', such as mutual funds, insurance companies, pension funds, hedge funds and central banks, rose significantly to $42 \%$. A much smaller proportion of trades (13\%) were carried out by nonfinancial businesses, such as manufacturing and airline companies. ${ }^{31}$

A CTT could work as follows: it would be assessed on individual foreign exchange transactions by interbank dealers and other financial intermediaries in the foreign exchange market and monitored and possibly collected by the main international foreign exchange settlement house, the Continuous Link Settlement Bank (CLS Bank), ${ }^{32}$ with support from central banks through their real-time gross-settlement systems. National authorities could then collect the tax from the CLS Bank in cooperation with central banks and with access to information provided by data cooperatives such as the Society for Worldwide Interbank Financial Telecommunications (SWIFT). ${ }^{33}$ The financial intermediaries and dealers would pay the tax and if there were no intermediary in the process (e.g. intra-group payments within a corporate group) then the taxpayer would become liable itself (i.e. the holding company). A country could apply the CTT on all wholesale transactions conducted by intermediaries (banks and other brokers) based within that country, independently of where the transactions are negotiated, the location of transferor or transferee or the place of settlement.

The CTT is similar to the Tobin Tax, but is different in important respects: the Tobin tax was intended to slow the flow of cross-border capital ('throw sand in the wheels') to enhance the ability of national authorities to

${ }^{30}$ See N. Baba and F. Packer, 'From Turmoil to Crisis: Dislocations in the FX Swap Market Before and After the Failure of Lehman Brothers', BIS Working Papers No 285, July 2009.

${ }^{31}$ See Triennial Central Bank Survey, above n 29, at 3.

${ }^{32}$ The Continuous Link Settlement System (CLS) and the Continuous Link Settlement Bank International (CLS Bank) were established in 2002 by the 17 leading central banks, which issue the world's reserve currencies and a group of leading banks and financial institutions. The CLS Bank holds the deposits of its member banks denominated in the currencies of its participating central banks in the CLS system so that if one member bank cannot fulfil its counterparty obligation to another CLS member, then the CLS Bank can draw on the defaulting member's relevant currency deposit to cover the obligation owed to the non-defaulting CLS member. In 2009, the CLS Bank settled approximately 55\% of the value of foreign exchange transactions. The other main settlement method is traditional correspondent banking which settles about $32 \%$ of the value of forex transactions.

${ }^{3}$ SWIFT operates a worldwide voluntary financial messaging network which exchanges information between banks and other financial institutions in order to facilitate interbank payments, but it does not clear and settle payments and therefore could not collect or deduct tax on transactions. See http://www.swift.com (visited 25 July 2010). 
conduct monetary policy and to prevent an exchange-rate crisis. This meant that the Tobin Tax had to be at a high enough rate $(0.50$ or $1.0 \%)$ to change investor behaviour, which led to the criticism that under certain circumstances it would significantly limit liquidity in the market, which could exacerbate a crisis. ${ }^{34}$ Instead, a CTT could be assessed at a low enough rate $(0.01 \%-1$ basis point or $0.005 \%$-one-half a basis point) so as not to limit liquidity unduly, while deterring only those transactions with such low spreads (less than 0.01 or $0.005 \%$ ) that it would not have an appreciable effect on liquidity nor on underlying economic activity.

\section{A. How high should the CTT rate be?}

In considering the rate at which the tax should be levied, it will be necessary to consider two factors: (i) how much the market will decline given the tax rate charged, and (ii) the market's capacity to pay the tax without unduly limiting liquidity. Schmidt estimates a fall in volume of transactions of $14 \%$ if the rate of one-half of a basis point $(0.005 \%)$ is levied. ${ }^{35}$ The market's capacity to pay the tax will depend in part on the depth of liquidity in the market and ability of dealers and clients to circumvent and avoid the tax. Some studies suggest significant 'market dampening' and 'leakage' would lead to a market reduction of $25 \%{ }^{36}$

Proponents of the CTT estimate that a low tax rate can generate substantial revenue even if only applied to a few reserve currencies (sterling and euro). ${ }^{37}$ The most comprehensive and realistic estimates of how much money a CTT can raise across the major currencies are from Schmidt and Baker. ${ }^{38}$ Based on 2007 data, Schmidt estimates that a coordinated CTT levied at $0.005 \%$ (one-half a basis point) applied to the leading reserve currencies would yield US $\$ 33.41$ billion a year. ${ }^{39}$ In contrast, a coordinated CTT at the same rate on all the major currencies except the dollar would yield US $\$ 21.24$ billion a year, and a coordinated tax on only the euro and sterling would yield US $\$ 16.52$ billion a year. His estimates are more realistic

34 Grahl and Lysandrou, above n 26, at 598-600.

35 Rodney Schmidt, The Currency Transaction Tax: Rate and Revenue Estimates (Toronto: United Nations/North-South Institute, 2008) 14.

${ }^{36}$ Dean Baker, 'The Benefits of a Financial Transaction Tax', http://www.cepr.net/documents/ publications/financial-transactions-tax-2008-12.pdf (visited 25 July 2010).

37 See Machiko Nissanke, 'The Tobin Tax for Development Finance' in Atkinson (ed), above n 2, at 72; see also Heikki Patomaki and Katarina Sehm-Patomaki, The Tobin Tax: How to Make it Real (Helsinki: The Network Institute for Global Democratisation, 1999).

38 See Schmidt, above n 35, at 14-17, and Baker, above n 36.

39 Schmidt's estimates for a CTT on the US dollar as one leg against all other currencies amounted to: US $\$ 28.8$ billion, while a CTT on the euro alone as one leg against all other currencies would yield US\$12.29 billion, and similarly on the yen alone against all other currencies would yield US\$5.59 billion, and sterling alone against all other currencies would yield US $\$ 4.98$ billion. Ibid. 
and much lower than what other CTT proponents had estimated because he gives more weight to market dampening as a result of the tax. ${ }^{40}$ Most of the volume reductions that result from the tax derive from the loss of short-term trading, such as algorithmic trading, that responds to very small spreads of less than one basis point which would be smaller than the estimated tax. On the other hand, his revenue estimates can be considered more optimistic because he minimizes the risk of avoidance and circumvention because of the expected effect of centralized settlement in the CLS Bank system which would make it very difficult to avoid paying the tax. ${ }^{41}$

Schmidt's higher estimates should be contrasted with those of other CTT and FTT advocates who adopt similar methodologies but give more weight to avoidance and circumvention. For instance, Baker estimated a CTT yield of only US $\$ 7.8$ billion that took into account a higher level of market reduction of $25 \%$ based on a tax rate of $0.01 \%$ (one basis point). ${ }^{42}$ Nissanke uses BIS data from 2001 to estimate that a global CTT at a rate of $0.02 \%$ applied to wholesale transactions would yield between US $\$ 30$ and US $\$ 35$ billion while at a rate of $0.01 \%$, it would yield between US $\$ 17$ and US $\$ 31$ billion a year. ${ }^{43}$ Schmidt's estimate of $\$ 33.41$ billion a year appears to be a realistic assessment of the capacity of the CTT to raise revenue based on the depth and liquidity of the foreign exchange markets and the institutional consolidation that is occurring in centralized settlement of foreign exchange transactions. ${ }^{44}$

In addition, the adoption of a CTT, and its rate, would have important implications for certain international financial centres, such as the UK's City of London which serves as the world's leading foreign exchange trading centre, with nearly $36.7 \%$ of the value of foreign exchange transactions taking place each day. ${ }^{45}$ UK policy-makers would understandably be concerned that such a tax might cause the migration of much of this business to other jurisdictions. At a $0.005 \%$ rate, however, it is difficult to show that a UK CTT of $0.005 \%$ - equivalent to a $£ 500$ charge for a $£ 10$ million transaction-would undermine London's status as the world's leading centre for foreign exchange trading.

${ }^{40}$ For example, this should be compared with the much higher estimate of US $\$ 176$ billion a year. J. Frankel 'How Well Do Markets Work: Might a Tobin Tax Help?' in Haq et al., above n 17 , at $41-82$.

${ }^{41}$ In light of the BIS Triennial Central Bank Survey 2010 survey, these estimates are rather cautious because they are based on average daily foreign exchange turnover of US $\$ 3$ trillion a day, and not on the 2010 survey's much higher turnover of US $\$ 4$ trillion a day.

${ }^{42}$ See Baker, above n 36.

${ }^{43}$ See Nissanke above $\mathrm{n} 37$.

${ }^{44}$ See Schmidt, above n 35.

${ }^{45}$ London is followed by the USA (18\%), Japan (6.2\%), Singapore (5.3\%), Switzerland (5.2\%), Hong Kong (4.7\%), Australia (3.8\%), France (3.0\%), Denmark (2.4\%), Germany $(2.1 \%)$. Triennial Central Bank Survey, above n 29, at 2. 


\section{B. Technical feasibility and incidence}

In considering the implementation and incidence of CTT, previous studies support the viability of administering such a tax in modern foreign exchange settlement systems. ${ }^{46}$ The CLS Bank, along with the CLS infrastructure, could permit CTTs to be imposed at a relatively low level, which has little effect on the relative costs of the transaction. For the CLS Bank to collect the tax, it would need the support of participating central banks, which issue the leading reserve currencies, to monitor wholesale gross-currency transactions through their real-time gross-settlement (RTGS) payment systems. Some central bankers, however, might emphasize that there is nothing in their mandate that would authorize them to support the CLS Bank in collecting a CTT. Understandably, central bankers charged with financial stability are very concerned about undermining market stability, and would therefore be concerned about any process that drove participants away from well-established and well-run existing markets, which might hinder liquidity and significantly raise transaction costs. This point is reinforced by the belief that the CLS Bank had performed well during the crisis and especially during the week in September 2008 when Lehman Brothers collapsed when it settled effectively $\$ 26.3$ trillion in foreign exchange payments despite disruptions in the foreign exchange swap market. Although central banks would probably like to see more use of the CLS Bank in settling forex transactions, because of the high transparency of the transactions and reduced settlement risk, they might have concerns with it collecting a CTT because this might drive transactions away from the CLS System, thereby increasing settlement risk.

Nevertheless, in an age when authorities have effectively nationalized the bulk of banking systems and where governments and central banks have purchased substantial quantities of hard to value private instruments, if regulators believe using a central settlement system promotes financial stability, then using such a system can be made mandatory for instruments to be legally valid or there could be higher capital-adequacy requirements for those not settling their trades in the central settlement system because, by settling outside the system, they are taking greater risks and possibly increasing systemic risk.

On the other hand, the incidence of the tax may create private costs that offset the social benefits from requiring the trade to be settled in a particular system. Foreign exchange trade encompasses a huge amount of different commercial activities with differing motivations. While foreign exchange speculation is one type of commercial activity taking place on the market, a large number of trade, investment, savings and pensions activitiesconducted by individuals and business entities at the retail and wholesale

\footnotetext{
${ }^{46}$ See Schmidt, above n 35, at 4.
} 
levels-involve the foreign exchange markets. As such, a large proportion of 'activity' on the foreign exchange market is already taxed in numerous ways. Also, foreign exchange trading supports international trade in goods and services and a tax on currency transactions might hinder international trade itself by increasing the cost of trade finance, especially for developing countries. It is uncertain whether it is desirable to try and exclude from the CTT those transactions that primarily support international trade because it might be difficult to differentiate between foreign exchange speculation and hedging transactions and currency transactions that are incidental to international trade. On the other hand, the size of the levy being proposed is unlikely to make any material difference to a corporate or real goods trade transaction. It may be useful to note that legal and banking fees on many of these transactions often amount to well in excess of $1.0 \%$ or 100 basis points. In large, cross-border corporate finance transactions, banks charge advisory fees, arrangement fees and commitment fees, and each of these is a large multiple of a basis point. In trade finance transactions, banking fees are similar, amounting to many multiples of a basis point.

Some critics, however, are sceptical that the tax would have a 'negligible effect'. While the proposed size of the levy $(0.005 \%$ or 0.5 basis points) appears very low, it is not low relative to the spreads for the most liquid exchange rates in the foreign exchange market such as euro/\$, $£ / \$, \mathrm{Sfr} / \$$ and $\$ \Psi$. In times of low volatility, spreads for these currencies were reported to stand at around one basis point, in which case a 0.5 basis point levy would be very significant. Nevertheless, it should be noted that the spread is not a reflection of trading profitability, but reflects the price of liquidity. Banks make profit from trading foreign exchange partly by charging for this liquidity, but primarily by following trends in the market place and in their customers' business.

Regarding the burden of the tax, it should be observed that in terms of information the foreign exchange market is primarily a wholesale market. Retail transactions are a very small proportion of total transactions. The burden of the tax will fall on those carrying out thousands of transactions over short periods of time-this is decidedly not retail, it is wholesale and is primarily algorithmic trading. For instance, a pension fund investor will execute transactions in a long-term fund a few times a year, while a hedge fund would do so hundreds of times.

V. FTT

A transaction tax could be applied to a broader range of financial assetsequities, bonds, swaps, options and an array of derivative instruments. Many developed and developing countries, such as Brazil and Japan, already impose broad-based taxes on futures and derivatives transactions and stocks and bonds, and some countries such as the UK have narrower 
taxes on equity shares traded on an exchange. ${ }^{47} \mathrm{~A}$ broader FTT could potentially raise substantial sums to defray the costs of financial crises and reduce the growing public resource gaps identified by international organizations. A broader FTT could be based on most instruments in OTC markets, such as interest rate swaps and currency swaps and options, and certain exchange-traded derivatives and futures. ${ }^{48}$

Although the tax could be levied at a rate similar to the CTT, it could be applied at different rates to reflect different risks posed by the instruments and different liquidity requirements in the markets in which the instruments trade. Dealing and trading in instruments outside the forex markets often involves a broader range of players located in multiple jurisdictions who use different clearing and settlement institutions and are exposed to different counterparty and market risks. To this end, Spahn has proposed that different tax rates apply to different counterparties (regulated banks, other financial institutions and private capital and non-financial corporations and public institutions) depending on their size and the systemic risk that they pose. ${ }^{49}$ This proposal assumes that some categories of counterparty (e.g. hedge funds) or transactions (e.g. certain derivative products) are more prone to speculative trading than others. Such a multi-tiered tax regime should aim to identify the desirable level of reduction in trading activities, which should be large enough to eliminate short-term speculative trading, but not so large as to limit unduly or hamper the normal functioning of markets.

Econometric analysis has estimated how much a broad FTT can raise across a wide number of financial instruments (including bonds, exchangetraded, centrally cleared and OTC derivatives).$^{50}$ For instance, Schulmeister incorporates conservative parameters for market dampening, avoidance and circumvention. Although his estimates are rather cautious, they provide probably the most accurate estimate to date of the market impact of a FTT at tax rates of $0.5,0.1$ or $0.01 \%$. Based on his methodology, if the lowest tax rate of $0.01 \%$ is applied to all exchange-traded and OTC derivatives, the estimated revenue would be between $\$ 100$ and $\$ 120$ billion a year. ${ }^{51}$ The broader FTT, unlike the CTT, would generate substantially higher revenue and would achieve regulatory objectives because it would

${ }^{47}$ See IMF Final Report, above n 12, Appendix 5.

48 The average daily value of the global OTC derivatives market is approximately US $\$ 24$ trillion per year (including credit default swaps, commodity contracts, equity derivatives, interest rate contracts, and FX contracts). Alexander et al., above n 18, at 52 .

49 Paul B. Spahn, 'On the Feasibility of a Tax on Foreign Exchange Transactions', http://www. wiwi.uni-frankfurt.de/profs/spahn/tobintax/Tobintax.pdf (visited 25 July 2010).

50 Stephan Schulmeister, 'A General Financial Transaction Tax: A Short Cut of the Pros, Cons and a Proposal', WIFO Working Papers No 344, 2009.

51 Schulmeister's parameters show that the lower tax rate of $0.01 \%$ would generate more revenue in absolute terms than the higher tax rates of 0.10 and $0.50 \%$ largely because of market dampening at the higher rates. 
be focused mainly on instruments with shorter term positions that consist of higher levels of leverage which pose greater systemic risk.

Recent regulatory initiatives in Europe and the USA will require most OTC derivatives and futures contracts to be traded and cleared on an organized exchange and/or clearing house. It would be advantageous to implement a FTT through centralized clearing and settlement structures. The trend towards centralized clearing and settlement of derivatives and foreign exchange transactions has made it much more feasible to implement a FTT on a global basis. Clearing houses already have sophisticated reporting processes for withholding tariffs and other charges and costs for dealers and other users and maintain up-to-date data on all cleared transactions. ${ }^{52}$ This type of centralized clearing and settlement network can provide vital information for use in assessing and reporting the applicable amount of tax owed for a FTT. Moreover, future regulatory reforms will provide incentives such as lower capital charges for intermediaries to clear their derivatives trades through clearing houses and therefore a small transaction tax of $0.01 \%$ (one basis point) or $0.005 \%$ (one-half of one basis point) would be a small price to pay for the cost savings and reduced risk of clearing trades through clearing houses.

For both the FTT and CTT, an international mechanism for distribution of the proceeds will have to be agreed by the participating states. Once collected, the revenue could be distributed first to the national authorities of the jurisdiction where the market participants paid the tax. These governments might then have an obligation to use a pre-agreed portion of the revenue for domestic regulatory programmes, or to reimburse the government for direct assistance to the financial sector. They would then distribute a pre-agreed portion of the revenue to international aid organizations to be used to promote the UN MDGs and reduce existing official sector resource gaps in support of overseas development programmes. In addition, some of the revenue could be designated for a global solidarity fund to pay for climate change initiatives and provide other global public goods. In this way, financial tax revenue could be used both to achieve regulatory objectives and provide global public goods.

\section{THE FTT/CTT AND WTO OBLIGATIONS}

Foreign exchange and OTC market activity has become much more global with the proportion of cross-border transactions increasing to $65 \%$ in 2010 from $62 \%$ in $2007 .{ }^{53}$ The significant increase in cross-border trading activity

\footnotetext{
${ }^{52}$ Robert Barnes, 'Counterparty Clearing House User Choice: An Evolving European Landscape', http://www.oxera.com/cmsDocuments/Agenda_March\%2010/Counterparty\%20 clearing\%20house $\% 20$ user\%20choice.pdf (visited 25 July 2010).

${ }^{53}$ BIS Triennial 2010 Survey, above n 29, at 4.
} 
in the financial markets raises some important issues regarding how a CTT or a FTT may impinge on World Trade Organization (WTO) commitments. The WTO General Agreement on Trade in Services (GATS) and its Annex on Financial Services provide the international legal framework for the regulation of cross-border trade in financial services. Although the jurisdictional scope of the GATS does not cover the liberalization of cross-border capital flows, it does cover cross-border money transfers or payments that are necessary for Members to fulfil their specific commitments on market access and national treatment.

Under Article XI(1) of the GATS, a Member may not restrict 'international transfers and payments for current transactions relating to its specific commitments.' In other words, restrictions on capital flows or payments that are necessary to make a payment for cross-border trade in a services sector or subsector that is subject to a GATS market access or national treatment commitment is not permitted under the GATS. Article XI provides:

Article XI: Payments and Transfers

1. Except under the circumstances envisaged in Article XII, a Member shall not apply restrictions on international transfers and payments for current transactions relating to its specific commitments.

Significantly, this prohibition on restrictions on international transfers and payments relates only to specific commitments made by WTO Members to liberalize their services sectors. For instance, where a Member has not made a liberalization commitment for a particular services sector, the Article XI prohibition would not apply. States have discretion through the WTO negotiation process to liberalize their services sectors on a sector-by-sector basis. Regarding financial services, most developed countries adopted in 1997 the Understanding on Commitments in Financial Services that sets out a blueprint for making liberalization commitments in financial services. The Understanding allows its 31 signatory members (counting the EU as one) to opt for a higher and more robust set of market-access and national treatment commitments.

The relevance of Article XI for the analysis of the CTT and FTT is that most developed countries and some developing countries that are WTO Members (i.e. the USA, the EU, Japan and some sub-Saharan African countries) have made substantial market-access commitments in many of their services sectors, thereby incurring an obligation under Article XI(1) not to impose any restrictions (including taxes or charges) on 'international transfers and payments' that relate to the provision of these cross-border services (including financial services). Although it is not clear whether the CTT and FTT are discriminatory measures under WTO jurisprudence, they could be interpreted as restrictions on cross-border transfers and payments related to specific commitments in violation of a Member's market access 
commitments under Article XVI GATS. The Annex on Financial Services, however, permits Members to depart from their GATS liberalization commitments (including the Article XI obligation not to impose restrictions on international transfers and payments) by adopting measures for a prudential reason that protect investors, depositors, policyholders or to maintain the stability and integrity of the financial system. ${ }^{54}$ This is known as the 'prudential carve-out' and it is intended to provide member governments discretion to adopt measures for a prudential reason that may have the effect of departing from their liberalization commitments in services sectors.

The FTT and CTT would arguably qualify for the 'prudential carve-out' because they can potentially be designed to achieve prudential regulatory objectives in the form of curbing excessive risk-taking, providing funds for bank resolution programmes and paying for the social costs of financial crises. However, if the FTTs or CTTs are designed largely to raise revenue to pay for global public goods, such as the UN MDGs and climate-change measures, unrelated to regulatory objectives, they will have difficulty withstanding a legal challenge by a WTO Member under Article XI of the GATS. $^{55}$

\section{CONCLUSION}

The article examines the advantages and disadvantages of several types of financial taxes, including a bank balance sheet tax, a CTT and a broader FTT. The article suggests that FTTs, especially those applied to currency transactions and exchange-traded and OTC derivatives, could serve regulatory objectives while raising sustainable revenue to assist governments in paying for the social costs of financial crises and providing global public goods. Nevertheless, financial policy-makers should consider what type of financial tax is most appropriate for their jurisdictions and then adopt international principles with other national authorities to govern their implementation in order to minimize arbitrage and circumvention.

\footnotetext{
54 Annex on Financial Services, Article 2(a). It states in relevant part: 'Notwithstanding any other provisions of the Agreement, a Member shall not be prevented from taking measures for prudential reasons, including for the protection of investors, depositors, policy holders, or persons to whom a fiduciary duty is owed by a financial service supplier, or to ensure the integrity and stability of the financial system.'

${ }^{55} \mathrm{Cf}$. also on prudential carve out in GATS papers by Cottier and Krajewsky, in this issue at 817-835.
} 